\section{Henry J.M. Barnett}

$\mathrm{H}$ enry J.M. Barnett, neurologist, known as Barney, was born in Newcastle-Upon-Tyne, United Kingdom, in 1922 and died in Toronto, Canada, on October 20, 2016. He was best known for randomized stroke-prevention trials: aspirin effectiveness to prevent stroke, ${ }^{1}$ lack of effectiveness of cerebral bypass, ${ }^{2}$ and effectiveness of carotid endarterectomy. ${ }^{3}$ Part of the success of these trials came from Barney's understanding of the value of an angiographic core lab for the studies; the success of the North American Symptomatic Carotid Endarterectomy Trial (NASCET) came, in part, from the core lab's insistence on consistent, reproducible stenosis quantification.

He was honored: Companion of the Order of Canada (the closest Canadian award to a UK knighthood), Honorary Doctor of Science at Oxford University, Stroke Research Award of Sweden's Karolinska Institute, and honorary membership in foreign medical societies including the Royal Society of Medicine (United Kingdom), Russian Academy of Medical Science, Indian Academy of Neurology, Hungarian Neurosurgical Society, and more.

He completed medical school at the University of Toronto in 1944, followed by Toronto residencies in medicine and neurology and then fellowships at Oxford and Queen Square. At Queen Square, he overlapped with Charlie Drake, a neurosurgery fellow. They developed both professional and personal relationships, with their families intertwined ever since (some of his grandchildren are Drakes).

In the late 1960s, he moved from Toronto's Sunnybrook Hospital to join Drake in London, Ontario, to form an innovative combined university clinical neurosciences department. After I was recruited there in 1976, I saw a special atmosphere of combining neurology and neurosurgery into one academic department, plus neuropathology and neuroradiology. The CNS department's academics gave it a prominent place at the university table beside medicine and surgery; neurology was not considered merely to be one of many subsets of medicine or neurosurgery one of surgery.

As Editor-in-Chief of Stroke, Barney was careful to recuse himself from manuscripts sent from his own department. As I worked closely with Barney, I saw a master at work. He was on a first-name basis with those at the highest levels of NINDS, the Medical Research Council of Canada (now CIHR), and the Heart and Stroke Foundation of Canada (HSFC). NASCET received the largest NIH grant to date for foreign research. He was instrumental in including the word "stroke" in HSFC's name, unlike the American Heart Association. He proposed a new London Research Institute with unique governance separate from both hospital and university. His fundraising abilities were formidable. He visited the Conservative Premier of Ontario and returned with a large grant supporting the planned institute, now named for John Robarts, a former premier who experienced a series of debilitating strokes. Then, Barney visited the Liberal Prime Minster of Canada, who added another large contribution.

Every few days, without prior notice, we in neuroradiology were summoned to Barney's office to display innovative interventional materials and images of successful interventional neurora-

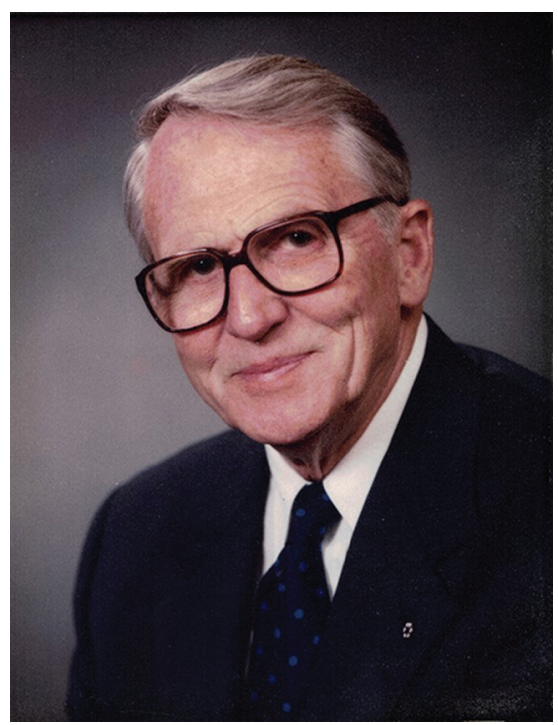

diology cases for yet another visiting leader of industry, wealthy potential donor, and even the American ambassador. One time, the CEO of a multinational company was flown in from Europe and diverted from New York for an urgent consultation with Barney in London after a spell in his overseas office. We fit in a sameday CT and IV DSA (it was 1982); Barney gave him a clean bill of health, and he left town with a seat on the Institute's board after pledging a six-figure donation. We can claim that our neuroradiology work enabled the founding of the Robarts Research Institute.

Barney had diverse connections. In the early 1990s, he was a stroke consultant for the famous Lubavitcher Rebbe, who had a stroke in New York. After Barney was called at Princeton, he was escorted to New York by police, who closed the Lincoln Tunnel to get him quickly to the Rebbe. That night, I received a FedEx package containing a CT with instructions to phone my interpretation to Barney. A few months later, Barney was invited to a wedding of one of the Rebbe's family members in a Manhattan square just beneath the languishing Rebbe's hospital window. Barney told me that he and Mayor Rudy Guiliani were the only ones in the crowd not wearing black coats and fedoras.

Although Barney is known for his work regarding stroke, earlier in his career, he contributed to spinal cord disease research by his discovery and report of posttraumatic syringomyelia. ${ }^{4}$ Even without his work on stroke, he was already a recognized syrinx expert, especially for his monograph Syringomyelia. ${ }^{5}$

He was seriously interested in birds and preserving nature. As a boy, he skipped Sunday school to frequent Toronto lagoons with his binoculars. During his career, he would tell various foreign hosts that he wished to see local birds and would often be led on a bird walk by an ornithology institute director or university biology chair. He was an advocate of the Nature Conservancy of Canada (NCC) for the Happy Valley Forest in King Township, north of Toronto, where he owned property acquired when his children were young. He passed on his passion for nature in forests, ponds, 
and meadows to his children, grandchildren, and great-grandchildren. NCC published his detailed blog of flora and fauna. ${ }^{6} \mathrm{His}$ successful campaign for preservation included hosting a Canadian Prime Minister in his own living room to drum up support. He was able to personally enable NCC with preservation of areas that housed threatened plant and animal species.

\section{REFERENCES}

1. Canadian Cooperative Stroke Study Group. A randomized trial of aspirin and sulfinpyrazone in threatened stroke. N Engl J Med 1978; 299:53-59 CrossRef Medline

2. EC/IC Bypass Study Group. Failure of extracranial-intracranial arterial bypass to reduce the risk of ischemic stroke. Results of an international randomized trial. N Engl J Med 1985;313:1191-200 CrossRef Medline
3. North American Symptomatic Carotid Endarterectomy Trial Collaborators. Beneficial effect of carotid endarterectomy in symptomatic patients with high-grade carotid stenosis. N Engl J Med 1991;325: 445-53 CrossRef Medline

4. Barnett HJ, Jousse AT, Morley TP, et al. Post-traumatic syringomyelia. Paraplegia 1971;9:33-37 CrossRef Medline

5. Barnett HJ, Foster JB, Hudgson P, eds. Syringomyelia. London: Saunders; 1973

6. Barnett HJ. Land Lines. Nature Conservancy of Canada blog. http:// www.natureconservancy.ca/en/blog/authors/dr-henry-barnett.html. Accessed November 17, 2016

A.J. Fox

Department of Neuroradiology Sunnybrook Health Sciences Centre University of Toronto Toronto, Canada

http://dx.doi.org/10.3174/ajnr.A5046 